\title{
EFEKTIVITAS METODE DARING BERBANTUAN VIDEO ANIMASI DALAM PEMBELAJARAN HURUF KANJI
}

\author{
Retno Dewi Ambarastuti ${ }^{1}$, Laily Amalia Savitri ${ }^{2}$ \\ ${ }^{1}$ Universitas Brawijaya, retnodewia@ub.ac.id \\ ${ }^{2}$ Universitas Brawijaya, laily.amalia@ub.ac.id
}

\begin{abstract}
ABSTRAK
Bagi pembelajar bahasa Jepang di Indonesia, Kanji menjadi salah satu hal yang sulit karena jumlah huruf yang banyak. Kesulitan belajar Kanji semakin bertambah karena sejak pemerintah menyatakan pandemi Covid-19, pembelajaran harus dilaksanakan secara daring. Salah satu strategi pembelajaran kanji melalui adalah dengan menggunakan bantuan video animasi dengan gambar dan cerita. Penelitian yang dilakukan adalah efektivitas penggunaan video berbantuan animasi dalam pembelajaran Kanji 2 pada Program Studi Sastra Jepang Universitas Brawijaya tahun akademik 2019/2020. Teori yang digunakan adalah pembelajaran daring dan blended learning, efektivitas pembelajaran, dan buku pembelajaran Kanji: Sutorii De Oboeru Kanji. Metode dalam penelitian ini adalah penelitian lapangan yang berupa penelitian deskriptif komparatif dengan metode preexperimental design dengan bentuk intact-group comparison. Objek penelitian adalah mahasiswa Program Studi Sastra Jepang yang memrogram mata kuliah Kanji 2 dengan total 97 orang. Hasil penelitian ini adalah 1) diketahui bahwa nilai rata-rata yang diperoleh mahasiswa dari hasil Ujian Akhir Semester di kelas eksperimen (Kelas A dan B), yakni 87 untuk Kelas A dan 95 untuk Kelas B, lebih tinggi daripada kelas kontrol (Kelas C dan D), yakni 85 untuk Kelas C dan 86 untuk kelas D; dan 2) metode pembelajaran daring berbantuan video animasi dengan gambar dan cerita Kanji dikatakan efektif atau berhasil.
\end{abstract}

Kata Kunci: pembelajaran daring, blended learning, efektivitas pembelajaran, video animasi, intactgroup comparison

\begin{abstract}
For Japanese learners in Indonesia, Kanji is one of the difficult things because of the large number of letters. The difficulty in learning Kanji has increased because since the government declared the Covid19 pandemic, learning has to be carried out online. One of the strategies for learning kanji is to use the help of animated videos with pictures and stories. The research conducted was the effectiveness of using animation-assisted videos in learning Kanji 2 in the Japanese Literature Study Program of Brawijaya University in the 2019/2020 academic year. The theory used is an online learning and blended learning, learning effectiveness, and the Kanji learning book: Sutorii De Oboeru Kanji. The method in this research is field research in the form of a comparative descriptive study with a pre-experimental design method in the form of intact-group comparison. The object of the research was the students of the Japanese Literature Study Program who programmed the Kanji 2 course with a total of 97 people. The results of this study are 1) it is known that the average score obtained by students from the results of the Final Semester Examination in the experimental class (Class A and B), namely 87 for Class A and 95 for Class B, is higher than the control class (Class C and D), namely 85 for Class $\mathrm{C}$ and 86 for class D; and 2) online learning methods assisted by animated videos with pictures and Kanji stories are said to be effective or successful.
\end{abstract}

Keywords: online learning, blended learning, learning effectiveness, animation video, intact-group comparison 


\section{PENDAHULUAN}

Bahasa menjadi salah satu kebutuhan untuk menguatkan hubungan antarnegara. Begitu pula halnya dengan bahasa Jepang. Banyak perusahaan Jepang yang mencari tenaga kerja Indonesia yang memiliki kualifikasi kemampuan bahasa Jepang di atas atau minimal setara dengan JLPT (Japanese Language Proficiency Test) level N3, misalnya seperti translator maupun interpreter. Untuk memenuhi pasar tenaga kerja ini, Program Studi Sastra Jepang Fakultas Ilmu Budaya Universitas Brawijaya terus mendorong mahasiswanya untuk memiliki keterampilan berbahasa Jepang setara minimal JLPT N3.

Dalam mempelajari bahasa Jepang, mahasiswa dituntut untuk menguasai empat keahlian dalam berbahasa, yakni mendengar, berbicara, membaca, dan menulis, yang diterapkan dalam enam mata kuliah keterampilan berbahasa Jepang. Keenam mata kuliah keterampilan berbahasa Jepang itu adalah Kanji, bunpou (tata bahasa), kaiwa (berbicata), choukai (menyimak), dokkai (membaca), dan sakubun (menulis). Apabila keenam keahlian tersebut diintegrasikan, maka dapat memaksimalkan siswa dalam memahami materi yang diajarkan di kelas.

Bagi pembelajar bahasa Jepang di Indonesia, Kanji menjadi salah satu "momok" yang menakutkan karena jumlah hurufnya banyak, banyaknya coretan, serta metode pembelajaran Kanji yang kurang memadai dan inovatif. Selama ini, metode pembelajaran Kanji adalah dengan menghafal melalui urutan penulisan, bushu (bagian-bagian datri Kanji), dan menulis Kanji secara berulang.

Kanji pada dasarnya merupakan tulisan ideografis yang memiliki makna dan cerita di setiap bagian-bagiannya. Misalnya saja Kanji 婚 (kon, menikah). Kanji 婚 memiliki bagian-bagian Kanji berupa Kanji 女(onna, perempuan), 氏 (uji, nama marga/nama keluarga), dan 日 (hi, hari). Kanji 婚 ini memiliki makna "hari berubahnya nama keluarga dari perempuan adalah hari saat menikah" (Beuckmann, 2015: 98). Di Jepang, pada umumnya nama marga perempuan akan berubah menjadi mengikuti nama marga laki-laki bila perempuan tersebut menikah dan masuk ke dalam keluarga laki-laki (suaminya). 
Selain itu, Kanji 温かい (atatakai, hangat (untuk benda)) memiliki bagianbagian Kanji berupa $\forall$ (bushu sanzui, tiga titik air), 日 (hi, hari/matahari), dan 皿 (sara, piring). Kanji 温かい ini memiliki makna “dengan sinar matahari, saya menghangatkan sup dalam piring (Beuckmann, 2015: 72). Dengan demikian, apabila kita meletakkan piring yang berisi cairan (misalnya sup) dan diletakkan di bawah sinar matahari, maka isi piring tersebut akan menjadi hangat. Kanji diajarkan pada program studi Sastra Jepang Fakultas Ilmu Budaya Universitas Brawijaya sejak semester 1, dan pada penelitian ini, sumber data penelitian adalah pembelajaran Kanji 2 pada Program Studi Sastra Jepang FIB UB.

Mata kuliah Kanji 2 dilaksanakan pada semester dua. Materi mata kuliah ini adalah Kanji dasar Bahasa Jepang, dengan menggunakan buku Basic Kanji Book Volume 2 sebagai materi utama. Pada awalnya, perkuliahan dilakukan secara luring (luar jaringan atau offline, atau perkuliahan di kelas), dengan metode ceramah. Dosen mengajarkan huruf kanji, baik dengan diberi contoh dengan menuliskan kanji di papan tulis, maupun menggunakan komputer. Kemudian mahasiswa mengerjakan tugas yang ada pada buku materi dan tugas menulis berulang kali pada buku tugas mahasiswa. Penulisan berulang kali ini merupakan latihan menulis agar mahasiswa dapat menghafalkan huruf kanji yang dipelajari. Namun, karena pandemi Covid-19 pembelajaran di kelas ditiadakan. Pemerintah melalui Kementerian Pendidikan dan Kebudayaan telah membuat kebijakan agar proses kegiatan belajar dari jenjang dasar hingga perguruan tinggi dilakukan di rumah sebagai upaya untuk mencegah penularan virus. Salah satu pencegahan penyebaran COVID-19 adalah melakukan kegiatan perkuliahan dan pembelajaran melalui daring, termasuk Mata Kuliah Kanji. Dengan adanya perubahan sistem perkuliahan dari sistem pembelajaran di kelas menjadi pembelajaran daring (dalam jaringan, online), maka menuntut dosen untuk kreatif dan inovatif dalam melaksanakan sistem perkuliahan.

Perkuliahan daring dilakukan dengan berbagai cara yang pada prinsipnya adalah dosen dapat menyampaikan materi perkuliahan ke mahasiswa hingga evaluasinya. Salah satu strategi pembelajaran tersebut adalah dengan berbantuan video animasi dengan gambar dan cerita pada kuliah Kanji 2. Video animasi yang 
dibuat ini berisi huruf kanji yang dipelajari pada hari itu, lalu disajikan juga bushunya (karakter dasar Kanji), jumlah goresan, onyomi, kunyomi, arti, contoh kata yang menggunakan huruf tersebut, dan urutan menulisnya, serta sedikit cerita mengenai pemahaman arti Kanji tersebut sehingga mudah dipahami oleh pembelajar. Video ini juga diiringi backsound music yang membuat suasana belajar semakin semangat. Penyajian video dengan menggunakan warna yang tidak banyak, sehingga pembelajar tetap fokus pada Kanji yang dipelajari. Kanji, arti, onyomi, kunyomi, dan semuanya itu disajikan dalam video animasi, sehingga pembelajar tidak merasa bosan belajar Kanji, meskipun cara penulisan Kanji yang dipelajarinya sudah rumit.

Berdasarkan latar belakang tersebut, disusun rumusan masalah tentang efektivitas metode pembelajaran kanji lewat daring menggunakan video animasi pembelajaran kanji dengan gambar dan cerita untuk mahasiswa program studi Sastra Jepang Universitas Negeri Surabaya yang memrogram mata kuliah Kanji 2 pada semester genap tahun akademik 2019/2020.

Penelitian ini dilakukan dengan tujuan untuk mengetahui dan menjelaskan efektivitas metode pembelajaran kanji melalui daring berbantuan video animasi dengan gambar dan cerita untuk mata kuliah Kanji 2 mahsiswa program studi Sastra Jepang Universitas Brawijaya, Sedangkan manfaat penelitaan, bagi dosen bermanfaat untuk memberikan gambaran metode pembelajaran kanji secara daring yang bisa dijadikan alternative pilihan dalam mengajar kanji. Kemudian untuk mahasiswa, diharapkan mampu meningkatkan keterampilan berbahasa Jepang, khususnya tentang huruf kanji dan dapat memotivasi belajar bahasa Jepang dengan tampilan video animasi yang menarik.

\section{PEMBELAJARAN DARING DAN BLENDED LEARNING}

Pembelajaran merupakan sebuah sistem yang membantu individu belajar dan berinteraksi dengan sumber belajar dan lingkungan. Pitchard (2009) menyatakan bahwa teori pembelajaran adalah sebuah proses perubahan perilaku sebagai hasil dari pengalaman atau percobaan. Teori ini memperoleh sebuah ilmu atau pengetahuan yang diperoleh dari proses belajar. Tujuannya bervariasi, bisa untuk menambah ilmu, pengetahuan, hingga keterampilan, melalui proses belajar berdasarkan instruksi- 
instruksi tertentu. Hasil akhir dari proses pembelajaran adalah perilaku yang berubah, terbentuk, atau terkontrol.

Pembelajaran kanji yang dilakukan adalah dengan metode dalam jaringan (daring) dengan menggunakan bantuan video animasi. Hasil dari pembelajaran ini adalah mempermudah proses pemahaman mahasiswa pada Kanji dan semakin bertambahnya pemahaman Kanji. Metode pembelajaran daring merupakan implementasi pendidikan jarak jauh pada perguruan tinggi yang bertujuan untuk meningkatkan pemerataan akses terhadap pembelajaran yang bermutu.

Dalam pembelajaran daring, terdapat tiga model pembelajaran yang dapat digunakan, yakni synchronous learning atau model pembelajaran sinkron, asynchronous learning atau model pembelajaran asinkron, dan hybrid learning (Suwarno, 2020). Synchronous learning adalah model pembelajaran daring atau jarak jauh yang dilakukan secara real-time melalui tatap muka, misalnya melalui media Zoom Meeting, Google Meet, Cisco Webex, dan lain-lain. Asynchronous learning adalah model pembelajaran yang terjadi melalui saluran daring sebagai mediasi untuk pembelajaran mandiri yang dilakukan tanpa interaksi secara tatap muka, misalnya melalui Google Classroom, Edmodo, dan lain sebagainya. Hybrid learning yang juga dikenal dengan istilah blended learning menurut Jones dan Turner (dalam Bryan dan Volchenkova, 2016: 24), melibatkan kombinasi dari dua bidang perhatian, yakni pendidikan dan teknologi pendidikan, sedangkan menurut Graham (Ibid.: 25) sistem blended learning menggabungkan antara instruksi secara tatap muka dengan instruksi yang dimediasi melalui komputer. Friesen juga menambahkan (Ibid.: 25) bahwa blended learning menunjukkan berbagai kemungkinan yang disajikan dengan menggabungkan internet dan media digital dengan bentuk ruang kelas yang mapan yang membutuhkan kehadiran kehadiran fisik bersama dari pengajar dan pembelajar.

Berdasarkan definisi di atas, dapat disimpulkan bahwa blended learning merupakan salah satu model pembelajaran daring dalam bentuk ruang kelas digital yang dilakukan dengan mengkombinasikan pembelajaran melalui tatap muka (terdapat instruksi dan interaksi secara langsung) dengan pembelajaran melalui saluran daring untuk pembelajaran mandiri (instruksi melalui sistem komputer dan 
tanpa melalui tatap muka). Pada penelitian ini, penulis menggunakan pembelajaran daring dengan bantuan video dalam pengajaran mata kuliah Kanji 2 sebagai media untuk pembelajaran secara mandiri (asynchronous learing).

\section{EFEKTIVITAS PEMBELAJARAN}

Efektivitas pembelajaran adalah ukuran keberhasilan dari suatu proses pembelajaran untuk mencapai tujuan pembelajaran. Menurut Deassy dan Endang (dalam Fathurrahman dkk, 2019: 844), efektivitas pembelajaran adalah belajar yang bermanfaat dan bertujuan bagi pembelajar untuk belajar keterampilan spesifik, ilmu pengetahuan, dan sikap dengan mudah, menyenangkan, dan dapat terselesaikan tujuan pembelajaran sesuai harapan. Pardomunan (Ibid.) menambahkan bahwa efektivitas pembelajaran dapat dikatakan berhasil apabila proses pembelajarannya mencapai sasaran yang diinginkan, baik dari segi tujuan pembelajaran dan prestasi pembelajar yang maksimal. Dengan demikian, efektivitas pembelajaran lebih mengacu kepada output atau hasil yang telah ditargetkan. Apabila hasil belajar mengalami peningkatan atau mencapai hasil yang maksimal, maka dapat dikatakan model pembelajaran tersebut efektif atau berhasil.

\section{BUKU PEMBELAJARAN KANJI: SUTORII DE OBOERU KANJI}

Buku pembelajaran Kanji merupakan karya Fusako Beuckman, Yoiko Watanabe, Kazuna Kuramachi, dan Hideo Takahashi, yang diterbitkan oleh Kuroshio Publisher pada November 2008. Buku ini berisi cara mempelajari Kanji dari asal-usul Kanji. Buku ini terdiri dari 3 tingkatan, yaitu tingkat dasar, menengah, dan menengah atas.

Pada penelitian ini digunakan 2 (dua) buku, yaitu Kanji Sutori de Oboeru jilid I (300 Kanji) dan jilid II (301-500). Hal ini disesuaikan dengan buku materi yang digunakan di Sastra Jepang, yaitu Basic Kanji Book Volume 2, sehingga mahasiswa mempelajari Kanji dengan menggunakan materi yang ada pada Basic Kanji Book, dan menggunakan suplemen materi yang ada pada buku Sutori de Oboeru Kanji jilid I dan II. 


\section{METODE PENELITIAN}

Penelitian ini merupakan penelitian lapangan yang berupa penelitian deskriptif komparatif dengan metode pre-experimental design dengan bentuk intact-group comparison. Menurut Sugiyono (2018: 74), pre-experimental design merupakan desain penelitian yang belum merupakan eksperimen sungguh-sungguh karena masih terdapat variabel-variabel luar yang ikut berpengaruh terhadap terbentuknya variabel dependen. Intact-group comparison design merupakan desain pre-eksperimental yang terdapat dua kelompok yang digunakan untuk penelitian, yaitu satu kelompok untuk ekperimen (yang diberikan perlakuan) dan satu kelompok lainnya sebagai kelompok kontrol (tidak diberikan perlakuan) (Sugiyono, 2018: 75). Paradigma penelitiannya dapat digambarkan sebagai berikut.

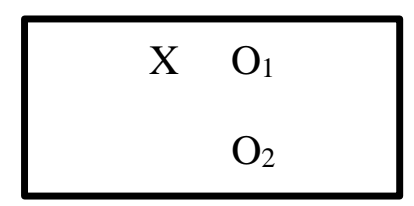

Keterangan:

$\mathrm{X}=$ treatmen yang diberikan (variabel independen)

$\mathrm{O}_{1}=$ hasil pengukuran kelompok yang diberikan perlakuan (variabel dependen)

$\mathrm{O}_{2}=$ hasil pengukuran kelompok yang tidak diberikan perlakuan (variabel dependen)

Kegiatan penelitian ini dilakukan pada Semester Genap Tahun Ajaran 2019/2020 pada bulan Maret 2020 hingga Juli 2020 di Program Studi Sastra Jepang Fakultas Ilmu Budaya Universitas Brawijaya.

Objek penelitian ini adalah mahasiswa Program Studi Sastra Jepang yang mengambil mata kuliah Kanji 2 pada Semester Genap Tahun Ajaran 2019/2020, yakni Kanji 2 kelas A, B, C, dan D yang keseluruhan berjumlah 97 orang. Pada penelitian ini, objek penelitian terbagi menjadi dua kelompok penelitian, yaitu (1) kelompok yang mendapat perlakuan dengan metode pembelajaran Kanji berbantuan video animasi dengan gambar dan cerita, dan (2) kelompok yang tidak mendapat perlakuan pembelajaran Kanji berbantuan video animasi (kelas kontrol). Kelompok yang mendapat perlakuan adalah mahasiswa Kanji 2 kelas A dan B, sedangkan kelompok 
yang tidak mendapat perlakuan (kelas kontrol) adalah mahasiswa Kanji 2 kelas C dan D.

Langkah-langkah kegiatan yang dilakukan dalam penelitian ini, yaitu:

1. Memetakan kanji-kanji bab 33 hingga bab 42 dari buku Basic Kanji Book Volume 2 dengan kanji-kanji tersebut yang terdapat pada buku Sutorii de Oboeru Kanji jilid I dan jilid II. Hal ini perlu dilakukan untuk memudahkan dalam pembuatan video animasi, karena pembagian bab dalam buku Basic Kanji Book Volume 2 berbeda dengan pembagian bab dari buku Sutorii de Oboeru Kanji jilid I dan jilid II.

2. Membuat video animasi gambar dan cerita Kanji dari kanji-kanji yang terdapat pada bab 33 hingga 42 dari buku Basic Kanji Book Volume 2 sebagai sumber materi utama. Gambar dan cerita Kanji diambil dari buku Sutorii de Oboeru Kanji jilid I dan jilid II yang memuat kanji-kanji dari sumber materi utama.

3. Memberikan video animasi gambar dan cerita tersebut kepada mahasiswa yang mengambil mata kuliah Kanji 2 kelas A dan B secara berkala setiap minggunya sesuai dengan materi yang diajarkan pada pertemuan tersebut sebelum perkuliahan dimulai untuk dapat dipelajari mahasiswa secara mandiri.

4. Dalam pertemuan tatap muka di kelas melalui saluran daring, dosen memberikan penjelasan singkat terkait materi yang sudah diberikan dalam video animasi bergambar dan cerita Kanji di kelas Kanji 2 A dan B yang mendapatkan perlakuan. Pada tahpa ini dosen juga turut melakukan observasi terhadap ketercapaian mingguan yang didapatkan oleh masing-masing individu.

5. Pada akhir semester dilakukan evaluasi akhir berupa Ujian Akhir Semester untuk seluruh mahasiswa yang mengambil mata kuliah Kanji 2, baik kelas A dan B yang mendapatkan perlakuan, maupun kelas C dan D yang tidak mendapatkan perlakuan (kelas kontrol). Soal yang diberikan untuk seluruh kelas ini sama.

6. Menghitung nilai rata-rata kelas dari Ujian Akhir Semester untuk setiap kelas.

7. Membandingkan nilai dan nilai rata-rata kelas dari kelas yang mendapatkan perlakuan (kelas A dan B) dengan nilai rata-rata kelas dari kelas yang tidak mendapatkan perlakuan (kelas C dan D). 
8. Menganalisis dari hasil perbandingan.

9. Menarik kesimpulan.

\section{METODE ANALISIS DATA}

Sebagaimana yang dijelaskan pada jenis penelitian sebelumnya, penelitian ini merupakan penelitian deskriptif komparatif dengan metode pre-experimental design dengan bentuk intact-group comparison. Meskipun penelitian ini menggunakan metode pre-experimental design dengan bentuk intact-group comparison, pada penelitian ini tidak menggunakan uji statistik (SPSS), namun dianalisis dengan deskriptif komparatif dari hasil pengukuran jumlah nilai rata-rata kelas dan jumlah persentase kelas yang mendapatkan nilai $\geq 80$ ( nilai $\geq 80$ tergolong memiliki kemampuan sangat baik). 


\section{PEMBAHASAN}

\section{NILAI RATA-RATA KELAS KONTROL DAN KELAS EKSPERIMEN}

Berdasarkan data yang diperoleh dari hasil Ujian Akhir Semester Kanji 2 pada Semester Genap 2019/2020, diketahui bahwa nilai rata-rata yang diperoleh mahasiswa di kelas kontrol (Kelas C dan D) adalah sebesar 85 untuk kelas C dan sebesar 86 untuk kelas D. Berikut ini adalah tabel data hasil Ujian Akhir Semester pada kelas kontrol.

Tabel 4.1 Nilai Rata-Rata Kelas Kontrol: Nilai Rata-Rata Kelas C (Kiri) dan Kelas D (Kanan)

\begin{tabular}{|c|c|c|}
\hline No & $\begin{array}{c}\text { Kode } \\
\text { Responden }\end{array}$ & $\begin{array}{c}\text { Nilai UAS } \\
\text { Kelas C }\end{array}$ \\
\hline 1 & R1 & $100 / 100$ \\
\hline 2 & R2 & $71 / 100$ \\
\hline 3 & R3 & $80 / 100$ \\
\hline 4 & R4 & $89 / 100$ \\
\hline 5 & R5 & $77 / 100$ \\
\hline 6 & R6 & $85 / 100$ \\
\hline 7 & R7 & $94 / 100$ \\
\hline 8 & R8 & $91 / 100$ \\
\hline 9 & R9 & $91 / 100$ \\
\hline 10 & R10 & $80 / 100$ \\
\hline 11 & R11 & $76 / 100$ \\
\hline 12 & R12 & $95 / 100$ \\
\hline 13 & R13 & $97 / 100$ \\
\hline 14 & R14 & $100 / 100$ \\
\hline 15 & R15 & $93 / 100$ \\
\hline 16 & R16 & $80 / 100$ \\
\hline 17 & R17 & $89 / 100$ \\
\hline 18 & R18 & $76 / 100$ \\
\hline 19 & R19 & $97 / 100$ \\
\hline 20 & R20 & $72 / 100$ \\
\hline 21 & R21 & $92 / 100$ \\
\hline 22 & R22 & $81 / 100$ \\
\hline 23 & R23 & $76 / 100$ \\
\hline 24 & R24 & $66 / 100$ \\
\hline Nilai Rata-Rata & $\mathbf{8 5 / 1 0 0}$ \\
\hline & & \\
\hline
\end{tabular}

\begin{tabular}{|c|c|c|}
\hline No & $\begin{array}{c}\text { Kode } \\
\text { Responden }\end{array}$ & $\begin{array}{c}\text { Nilai UAS } \\
\text { Kelas D }\end{array}$ \\
\hline 1 & R1 & $95 / 100$ \\
\hline 2 & R2 & $88 / 100$ \\
\hline 3 & R3 & $100 / 100$ \\
\hline 4 & R4 & $95 / 100$ \\
\hline 5 & R5 & $93 / 100$ \\
\hline 6 & R6 & $90 / 100$ \\
\hline 7 & R7 & $88 / 100$ \\
\hline 8 & R8 & $90 / 100$ \\
\hline 9 & R9 & $100 / 100$ \\
\hline 10 & R10 & $97 / 100$ \\
\hline 11 & R11 & $77 / 100$ \\
\hline 12 & R12 & $86 / 100$ \\
\hline 13 & R13 & $82 / 100$ \\
\hline 14 & R14 & $76 / 100$ \\
\hline 15 & R15 & $72 / 100$ \\
\hline 16 & R16 & $85 / 100$ \\
\hline 17 & R17 & $78 / 100$ \\
\hline 18 & R18 & $82 / 100$ \\
\hline 19 & R19 & $77 / 100$ \\
\hline 20 & R20 & $84 / 100$ \\
\hline 21 & R21 & $85 / 100$ \\
\hline 22 & R22 & $77 / 100$ \\
\hline Nilai Rata-Rata & $\mathbf{8 6 / 1 0 0}$ \\
\hline & &
\end{tabular}

Berdasarkan data yang diperoleh dari hasil Ujian Akhir Semester Kanji 2 pada Semester Genap 2019/2020, diketahui bahwa nilai rata-rata yang diperoleh mahasiswa 
di kelas eksperimen (Kelas A dan B) adalah sebesar 87 untuk kelas A dan sebesar 95 untuk kelas B. Berikut ini adalah tabel data hasil Ujian Akhir Semester pada kelas eksperimen.

Tabel 4.2 Nilai Rata-Rata Kelas Kontrol: Nilai Rata-Rata Kelas A (Kiri) dan Kelas B (Kanan)

\begin{tabular}{|c|c|c|}
\hline No & $\begin{array}{c}\text { Kode } \\
\text { Responden }\end{array}$ & $\begin{array}{c}\text { Nilai UAS } \\
\text { Kelas A }\end{array}$ \\
\hline 1 & $\mathrm{R} 1$ & $38 / 100$ \\
\hline 2 & $\mathrm{R} 2$ & $80 / 100$ \\
\hline 3 & R3 & $92 / 100$ \\
\hline 4 & $\mathrm{R} 4$ & $100 / 100$ \\
\hline 5 & R5 & $91 / 100$ \\
\hline 6 & R6 & $91 / 100$ \\
\hline 7 & $\mathrm{R} 7$ & $93 / 100$ \\
\hline 8 & $\mathrm{R} 8$ & $90 / 100$ \\
\hline 9 & R9 & $91 / 100$ \\
\hline 10 & R10 & $86 / 100$ \\
\hline 11 & R11 & $86 / 100$ \\
\hline 12 & R12 & $81 / 100$ \\
\hline 13 & R13 & $100 / 100$ \\
\hline 14 & R14 & $91 / 100$ \\
\hline 15 & R15 & $82 / 100$ \\
\hline 16 & R16 & $91 / 100$ \\
\hline 17 & $\mathrm{R} 17$ & $100 / 100$ \\
\hline 18 & R18 & $87 / 100$ \\
\hline 19 & R19 & $92 / 100$ \\
\hline 20 & $\mathrm{R} 20$ & $92 / 100$ \\
\hline 21 & $\mathrm{R} 21$ & $96 / 100$ \\
\hline 22 & R22 & $100 / 100$ \\
\hline 23 & R23 & $87 / 100$ \\
\hline 24 & R24 & $85 / 100$ \\
\hline 25 & $\mathrm{R} 25$ & $50 / 100$ \\
\hline 26 & R26 & $100 / 100$ \\
\hline 27 & $\mathrm{R} 27$ & $78 / 100$ \\
\hline \multicolumn{2}{|c|}{ Nilai Rata-Rata } & $87 / 100$ \\
\hline
\end{tabular}

\begin{tabular}{|c|c|c|}
\hline No & $\begin{array}{c}\text { Kode } \\
\text { Responden }\end{array}$ & $\begin{array}{c}\text { Nilai UAS } \\
\text { Kelas B }\end{array}$ \\
\hline 1 & R1 & $93 / 100$ \\
\hline 2 & R2 & $100 / 100$ \\
\hline 3 & R3 & $88 / 100$ \\
\hline 4 & R4 & $100 / 100$ \\
\hline 5 & R5 & $100 / 100$ \\
\hline 6 & R6 & $98 / 100$ \\
\hline 7 & R7 & $83 / 100$ \\
\hline 8 & R8 & $94 / 100$ \\
\hline 9 & R9 & $97 / 100$ \\
\hline 10 & R10 & $81 / 100$ \\
\hline 11 & R11 & $97 / 100$ \\
\hline 12 & R12 & $100 / 100$ \\
\hline 13 & R13 & $98 / 100$ \\
\hline 14 & R14 & $100 / 100$ \\
\hline 15 & R15 & $90 / 100$ \\
\hline 16 & R16 & $89 / 100$ \\
\hline 17 & R17 & $100 / 100$ \\
\hline 18 & R18 & $100 / 100$ \\
\hline 19 & R19 & $97 / 100$ \\
\hline 20 & R20 & $100 / 100$ \\
\hline 21 & R21 & $95 / 100$ \\
\hline 22 & R22 & $89 / 100$ \\
\hline 23 & R23 & $93 / 100$ \\
\hline 24 & R24 & $97 / 100$ \\
\hline Nilai Rata-Rata & $\mathbf{9 5 / 1 0 0}$ \\
\hline & & \\
\hline
\end{tabular}

Berdasarkan Tabel 4.1 dan 4.2 di atas, dapat diketahui bahwa nilai rata-rata Ujian Akhir Semester kelas kontrol, yakni nilai rata-rata sebesar 85 pada kelas C dan 
nilai rata-rata sebesar 86 pada kelas $\mathrm{D}$, lebih rendah bila dibandingkan dengan nilai rata-rata Ujian Akhir Semester kelas eksperimen, yakni nilai rata-rata sebesar 87 pada kelas A dan nilai rata-rata sebesar 95 pada kelas B. Hal ini menunjukkan bahwa pembelajaran daring berbantuan video animasi dengan gambar dan cerita mampu meningkatkan rata-rata kemapuan kelas bahkan hingga bisa mendekati hasil yang maksimal (nilai 95 dari 100).

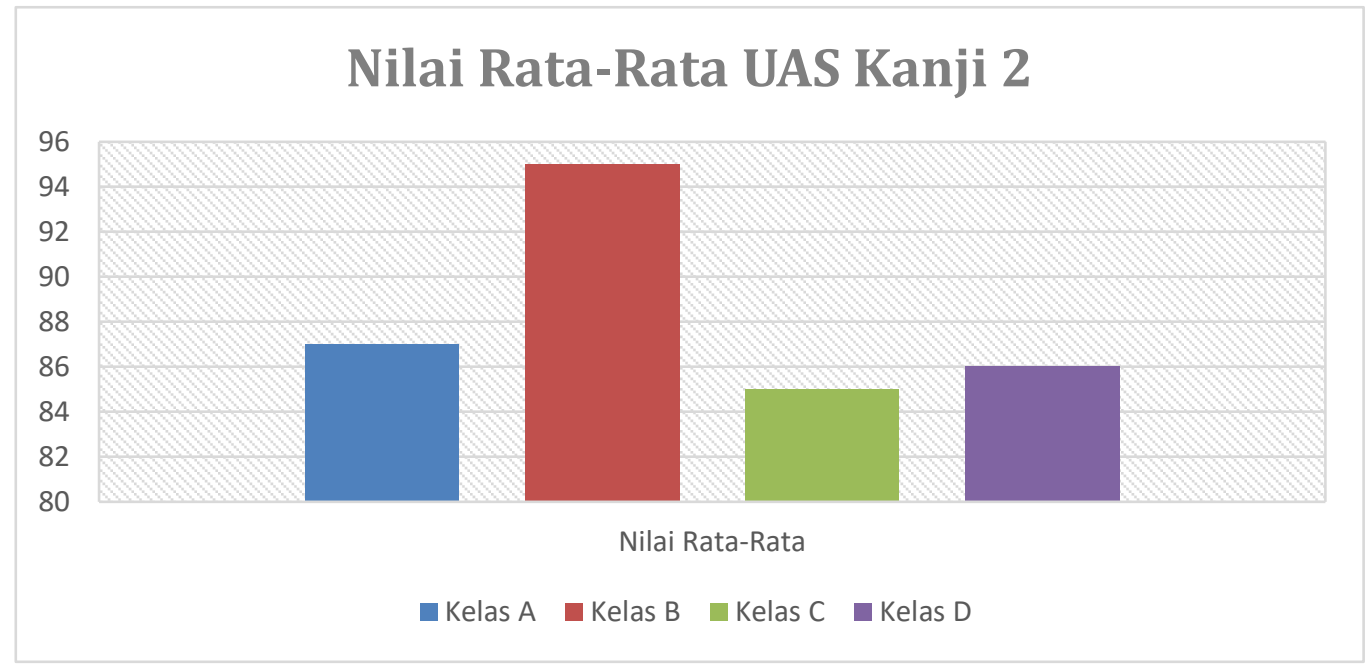

Gambar 4.1 Diagram Nilai Rata-Rata Kelas pada Ujian Akhir Semester Kanji 2

Namun, bila melihat nilai rata-rata kelas kontrol C dan D dengan kelas eksperimen A, diketahui bahwa meskipun pada kelas eksperimen A rata-rata kemampuan kelas dengan metode daring berbantuan video animasi menunjukkan hasil yang lebih tinggi bila dibandingkan dengan rata-rata kemampuan kelas kontrol C dan D, namun selisih nilai rata-rata antara kelas eksperimen A dengan kelas kontol $\mathrm{C}$ dan D tidak begitu signifikan, yakni hanya selisih 1 hingga 2 poin saja. Hal ini berbeda dengan selisih nilai rata-rata antara kelas eksperimen B dengan kelas kontrol $\mathrm{C}$ dan D yang memiliki selisih 9 hingga 10 poin.

Hal tersebut dapat saja terjadi karena masih terdapat variabel lain yang menentukan atau ikut berpengaruh terhadap terbentuknya variabel dependen sehingga mempengaruhi nilai rata-rata kelas, yakni kemampuan pada masing-masing individu tersebut. Berdasarkan Tabel 4.2 dapat diketahui bahwa responden dengan kode R1 dan R25 pada kelas A memiliki nilai Ujian Akhir Semester sebesar 38 dan 50. Nilai 
Ujian Akhir Semester R1 dan R25 ini berada jauh di bawah nilai rata-rata kelas A, yakni 87. Selain itu, nilai R1 dan R25 pada kelas A ini merupakan dua nilai terendah dari nilai Uajian Semester Kanji 2 pada Semester Genap Tahun Ajaran 2019/2020.

Berdasarkan hasil observasi kelas, responden R1 dan R25 pada kelas A memiliki ketercapaian target mingguan yang juga lebih rendah rendah daripada ratarata kelas. Hal ini menunjukkan bahwa kemampuan masing-masing individu, yakni responden $\mathrm{R} 1$ dan $\mathrm{R} 25$, berada di bawah rata-rata kemampuan masing-masing individu lainnya. Hal ini merupakan salah satu faktor atau variabel luar yang mempengaruhi hasil kemampuan dari kelas yang mendapatkan perlakuan.

\section{EFEKTIVITAS METODE DARING BERBANTUAN VIDEO ANIMASI}

Berdasarkan gambar 4.1, dapat diketahui bahwa 17 mahasiswa dari 24 mahasiswa (71\% mahasiswa) pada kelas $\mathrm{C}$ memiliki nilai $\geq 80$ dan 16 mahasiswa dari 22 mahasiswa (72\% mahasiswa) pada kelas $\mathrm{D}$ memiliki nilai $\geq 80$ dengan skor maksimalnya 100. Pada Tabel 4.2 di atas, dapat diketahui bahwa 24 mahasiswa dari 27 mahasiswa (89 \% mahasiswa) pada kelas A memiliki nilai $\geq 80$ dan 24 mahasiswa dari 24 mahasiswa (100\%) pada kelas B memiliki nilai $\geq 80$ dengan skor maksimalnya 100.

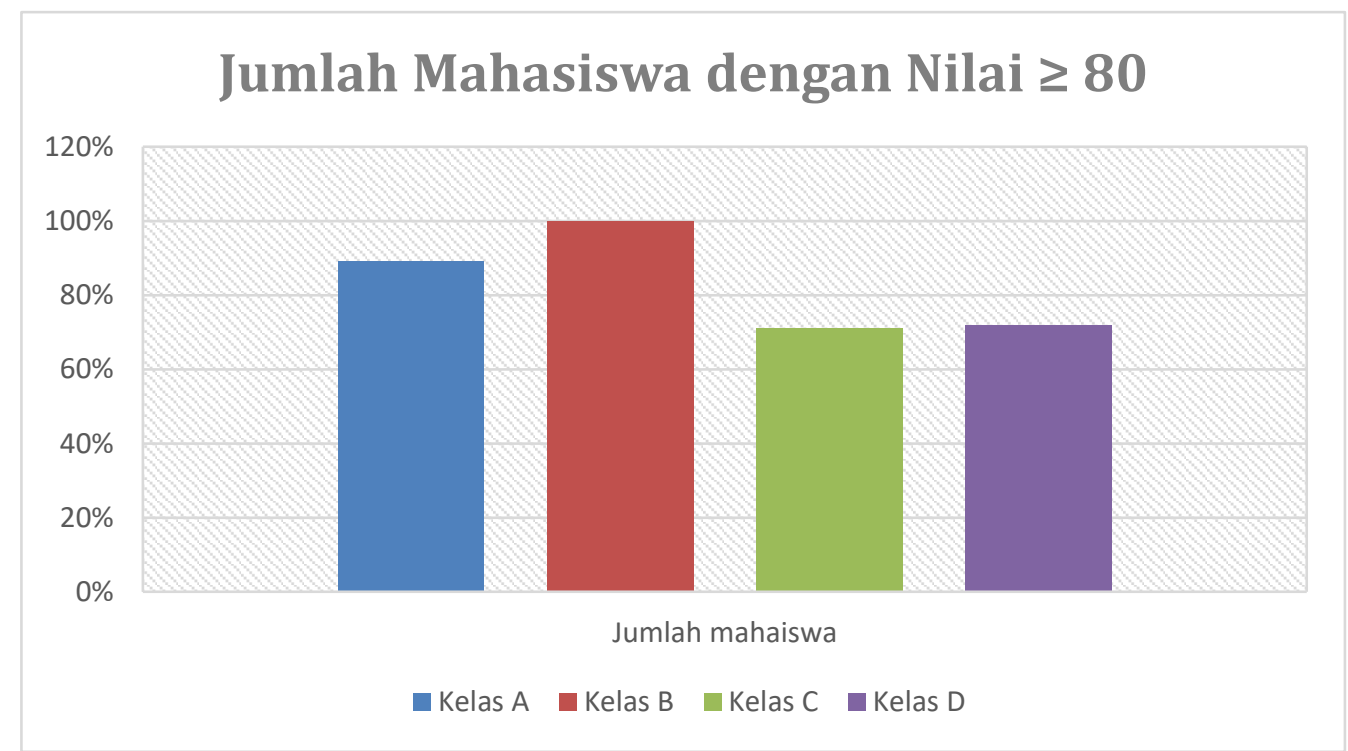

Gambar 4.2 Diagram Persentase Jumlah Mahasiswa dengan Nilai $\geq 80$ pada Ujian Akhir Semester Kanji 2 
Berdasarkan gambar 4.2 dapat diketahui bahwa 2 mahasiswa dari 24 mahasiswa (8\% mahasiswa) pada kelas C memperoleh nilai 100 dan 2 mahasiswa dari 22 mahasiswa (9\% mahasiswa) pada kelas D memperoleh nilai 100 dengan skor maksimalnya 100. Pada Tabel 4.2 di atas, dapat diketahui bahwa 5 mahasiswa dari 27 mahasiswa (19\% mahasiswa) pada kelas A memperoleh nilai 100 dan 8 mahasiswa dari 24 mahasiswa (33\%) pada kelas B memperoleh nilai 100 dengan skor maksimalnya 100 .

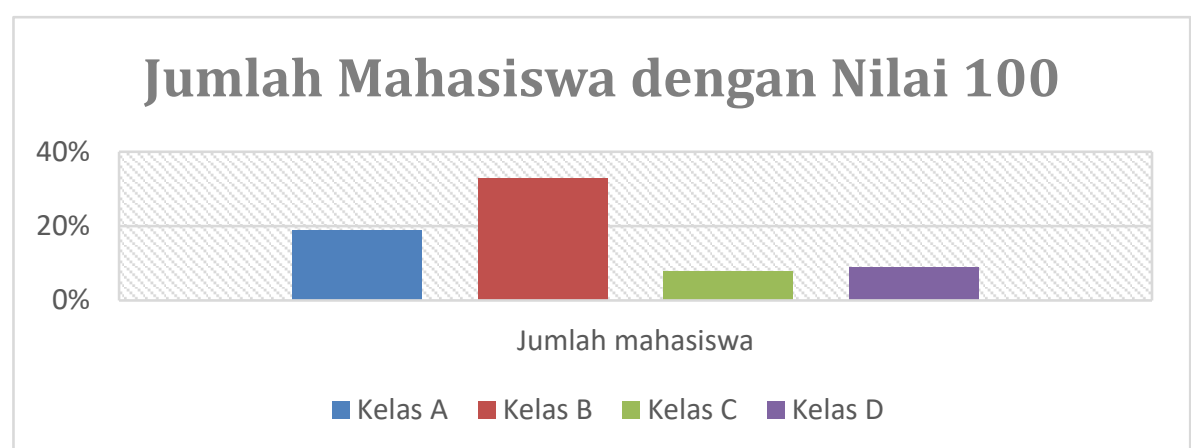

Gambar 4.3 Diagram Persentase Jumlah Mahasiswa dengan Nilai 100 pada Ujian Akhir Semester Kanji 2

Berdasarkan Gambar 4.2 dan Gambar 4.3, dapat diketahui bahwa kelas yang mendapatkan metode pembelajaran daring dengan berbantuan video animasi Kanji dengan gambar dan cerita memiliki efektivitas ketercapaian hasil yang tinggi atau maksimal bila dibandingkan dengan kelas yang tidak mendapatkan metode pembelajaran daring berbantuan video animasi kanji dengan gambar dan cerita. [ sebanyak $71 \%$ pada kelas C dan $72 \%$ pada kelas D. Selain itu, sebanyak $19 \%$ mahasiswa pada kelas A dan 33\% mahasiswa pada kelas B memperoleh hasil yang maksimal pada Ujian Akhir Semester Kanji 2 bila dibandingkan dengan kelas C yang hanya $8 \%$ mahasiswa dan kelas D yang hanya $9 \%$ mahasiswa saja yang memperoleh hasil yang maksimal pada Ujian Akhir Semester Kanji 2. Berdasarkan hal ini dapat disimpulkan bahwa metode pembelajaran daring berbantuan video animasi dengan gambar dan cerita Kanji dikatakan efektif atau berhasil. 


\section{SIMPULAN}

Berdasarkan hasil dan pembahasan sebelumnya, disimpulkan bahwa metode pembelajaran daring berbantuan video animasi dengan gambar dan cerita mampu meningkatkan rata-rata kemapuan kelas bahkan hingga bisa mendekati hasil yang maksimal. Meskipun demikian, masih terdapat variabel lain yang menentukan atau ikut berpengaruh terhadap terbentuknya variabel dependen sehingga mempengaruhi nilai rata-rata kelas, yakni kemampuan pada masing-masing individu tersebut.

Selain itu, metode pembelajaran daring dengan berbantuan video animasi Kanji dengan gambar dan cerita memiliki efektivitas ketercapaian hasil yang tinggi atau maksimal bila dibandingkan dengan kelas yang tidak mendapatkan metode pembelajaran daring berbantuan video animasi kanji dengan gambar dan cerita. Dengan demikian, dapat dapat disimpulkan bahwa metode pembelajaran daring berbantuan video animasi dengan gambar dan cerita Kanji dikatakan efektif atau berhasil diterapkan dalam pembelajaran Kanji. Dengan penelitian ini diharapkan dapat menjadi dasar untuk penelitian selanjutnya dengan mengembangkan media yang lebih menarik dalam proses pembelajaran kanji.

\section{DAFTAR PUSTAKA}

Beuckmann F., \& Iwasaki Y. 2015. Sutorii de Oboeru Kanji II 300: Learning 300 Kanji Through Stories (Ed. Ke-6). Tokyo, Jepang: Kurosio. 2015. Sutorii de Oboeru Kanji II 301-500: Learning Kanji Through Stories II 301-500 (Ed. Ke-3). Tokyo, Jepang: Kurosio.

Bryan, A., dan Volchenkova, K.N. 2016. Blended Learning: Definition, Models, Implications for Higher Education. Bulletin of South Ural State University, Ser. Education, Educational Sciences 8, no. 2: 24-30.

Fathurrahman, Arif, Sumardi, Yusuf, Adi E., dan Harijanto Sutji. 2019. Peningkatan Efektivitas Pembelajaran melalui Peningkatan Kompetensi Pedagogik dan Teamwork. Manajemen Pendidikan 7, no. 2: 843-850.

Sugiyono. 2018. Metode penelitian kuantitatif, kualitatif, dan $r \& d$. Bandung, Indonesia: Alfabeta.

Suwarno, Peter. 2020. Teaching Indonesian Language to Non-Native Speakers in Digital Era. Dalam Webinar Teaching Language to Non-Native Speakers in Digital Era. 8 Agustus 2020. Universitas Diponegoro. 